Revista de Filología Románica

ISSN: 0212-999X

http://dx.doi.org/10.5209/RFRM.63506

\title{
A carta, a coisa, a chave, a máquina do mundo ${ }^{1}$
}

\author{
Manaíra Aires Athayde ${ }^{2}$
}

Recibido: 5 de febrero de 2018 / Aceptado: 7 de octubre de 2018

Resumo. Este ensaio propõe um diálogo entre a poesia de Ruy Belo (Portugal, 1933-1978) e a de Carlos Drummond de Andrade (Brasil, 1902-1987), procurando mostrar como tais obras partilham de determinadas técnicas, elementos estilísticos e núcleos temáticos, além de referências comuns, importantes em seus processos de criação, como a obra de Charles Chaplin e a de Charles Baudelaire. O nosso intuito é, através de um caminho de análise e confronto daquelas artesanias poéticas, procurar compreender como certas perspectivas que aqueles dois poetas têm da poesia se entrecruzam.

Palavras-chave: Ruy Belo; Carlos Drummond de Andrade; poesia; diálogo.

\section{[en] The letter, the thing, the key, the world machine}

\begin{abstract}
This essay proposes a dialogue between the poetry of Ruy Belo (Portugal, 1933-1978) and Carlos Drummond de Andrade (Brazil, 1902-1987), explaining how these works share techniques, stylistic elements and thematic groups, as well as common references, important in their creative processes, such as the works of Charles Chaplin and Charles Baudelaire. Through the analysis and confrontation of these poetic works, our intention is to understand how their individual perspectives on poetry intersect each other.
\end{abstract}

Keywords: Ruy Belo; Carlos Drummond de Andrade; poetry; dialogue.

Sumario: 1. Uma jovem, com asas de pássaro; 2. Morte secreta; 3 . E de repente, a porta ou a chave; 4. José e o boi contraditório; 5 . A flor, no coração da máquina; 6 . Referências bibliográficas.

Cómo citar: Aires Athayde, M. (2019). A carta, a coisa, a chave, a máquina do mundo, en Revista de Filología Románica 36, 63-87.

\section{Uma jovem, com asas de pássaro}

Uma jovem, com asas de pássaro, cai no telhado de um escritor, no Chile. Ele passa a cuidar dessa "criatura alada", que então começa a atrair várias pessoas que acreditam nos seus poderes milagrosos. Até que um dia é sequestrada e levada para Londres, onde passam a ganhar dinheiro apresentando a freak como um anjo. A "mulher-an-

\footnotetext{
1 Este ensaio faz parte de um projeto maior, que culminou na tese de doutoramento Ruy Belo e o Modernismo Brasileiro. Poesia, Espólio, realizada na Universidade de Coimbra, com auxílio de bolsa Capes.

2 Centro de Literatura Portuguesa (CLP), Universidade de Coimbra

Email: mana_aires@hotmail.com
} 
jo", a partir de então, atravessa um longo caminho infernal, marcado pela violência e pela desumanização. Aqui, observamos Charles Chaplin colocar-se e colocar-nos mais uma vez numa posição empática para com uma personagem à margem da sociedade. Recorre ao estranhamento para provocar mais estranhamento, pondo em xeque os valores de um mundo tomado por injustiças, preconceitos e crueldades, e se mostrando completamente solidário com os que não têm voz, como aquela protagonista sem nome de The Freak. É a este filme, precisamente, que Ruy Belo se refere em «Uma árvore na minha vida», no início de um dos mais longos poemas de Toda a Terra:

Fora uma pessoa despreocupada ao longo de toda

a vida um dia porém conheci a mulher alada

por charlie chaplin somente em the freak conhecida e transfigurada

conheci-a e desde esse dia nunca mais fui nada

(Belo 2009: 676 e 677; itálico nosso)

À partida, a nossa conjectura é a de que esse nada pode potenciar, de maneira bastante sintomática, como já veremos, a convergência entre aspectos que encontramos na modernidade de Ruy Belo e, também, na obra daquele que sabe o «Canto ao homem do povo Charlie Chaplin»:

Era preciso que um poeta brasileiro, não dos maiores, porém dos mais expostos à galhofa, girando um pouco em tua atmosfera ou nela aspirando a viver como na poética e essencial atmosfera dos sonhos lúcidos,

era preciso que esse pequeno cantor teimoso, de ritmos elementares, vindo da cidadezinha do interior onde nem sempre se usa gravatas mas todos são extremamente polidos e a opressão é detestada, se bem que o heroísmo se banhe em ironia,

era preciso que um antigo rapaz de vinte anos, preso à tua pantomima por filamentos de ternura e riso dispersos no tempo, viesse recompô-los e, homem maduro, te visitasse para dizer-te algumas coisas, sobcolor de poema.

(Andrade 1988: 178)

Neste poema, depois destas três primeiras estrofes, Carlos Drummond de Andrade revisita cenas dos filmes protagonizados por Carlitos (ou Charlot), ${ }^{3}$ o mais conhecido personagem de Chaplin. Sem obedecer a uma ordenação cronológica ou a um levantamento exaustivo, o nosso gauche leva para o seu universo poético, num profundo gesto de identificação, uma série de elementos temáticos, estilísticos e retóricos encontrados na arte cinematográfica daquele ícone do cinema mudo. É significativo reparar que enquanto Drummond mobiliza as lembranças em torno desses filmes estrelados pelo personagem-mito, a película de Chaplin a que Ruy Belo

Recordemos: Para Ganhar a Vida (1914), O Emigrante (1917), Vida de Cachorro (1918), O Garoto (1921), A Corrida do Ouro (1925), O Circo (1929), Luzes da Cidade (1931), Tempos Modernos (1936) e O Ditador (1940). 
recorre é precisamente a que ficou inacabada, aquela de que se sabe muito pouco e que não cumpriu o seu caminho prometido. ${ }^{4}$

Se considerarmos que ambos são poetas que atingem estados outonais, digamos que Ruy Belo é aquele para o qual tudo se fica inacabado - como evidenciam as suas eternas despedidas, sempre a encenar o fim -, o que não poderia deixar de se refletir na estrutura dos seus poemas longos, enquanto "um modo de se dedicar como quem procura uma forma para o seu destino" (Gusmão 2010: 453). Quer dizer, "o alongamento dos versos tem o objecto correlativo no 'caminhar da vida', verificando-se assim uma afinação entre representação formal e representação temática" (Serra 2003: 70). Desse modo, com um poema longo narrativo constituído por partes processuais, que escandem a duração do poema pelas tensões muitas vezes concentradas na sensação de incompletude ou inconcretude, ou mesmo de impossibilidade, Ruy Belo é um poeta que parece amadurecer sem, no entanto, envelhecer, estando sempre exposto a "uma experiência acumulada que se pode(ria) repetir" (idem: 15). Por isso, o caminho em direção à morte não é bem o caminho em que se envelhece, é sempre um retorno à infância e à juventude ficcionadas, na impossibilidade de tê-las novamente. Como afirma Clara Rowland, "aqui, é a caducidade do tempo que faz do homem um tronco "vergado"” (Rowland 2015: 262).

Já Carlos Drummond de Andrade seria, nesses pressupostos, um poeta que envelheceu ao amadurecer (o que é a velhice, se os seus ombros suportam o mundo?), reconhecendo de maneira consciente e resoluta as fatalidades ou os obstáculos do caminho - a pedra, a Coisa, o embrulho, a carta, a chave, a máquina do mundo. Em Drummond, a especulação da palavra é tida como especulação para o desenvolvimento do poema, e a enunciação sempre feita a partir da palavra é validada para logo em seguida invalidar a palavra. No poema «Carta», de Claro Enigma, por exemplo, a carta vai sendo escrita à medida que o poema é escrito negando a possibilidade de escrita dessa carta. A carta é o rápido sonho "que se vai, de mandar / notícias amorosas / quando não há amor / a dar ou receber; / Quando só há lembrança / ainda menos, pó" (Andrade 1988: 236). "Contudo, esta é uma carta", afirma o último verso, resgatando aquela concretude, por assim se dizer, que há também na "estrada de pó e de esperança" que se lê no verso derradeiro de "Canto ao homem do povo Charlie Chaplin».

Aliás, os últimos versos deste poema ("ó Carlito, ${ }^{5}$ meu e nosso amigo, teus sapatos e teu bigode / caminham numa estrada de pó e de esperança"), memorando as várias vezes que Chaplin encerra as aventuras de Carlitos fazendo-o caminhar pelas brumas de uma estrada sem fim, são representativos de uma estrutura típica, a partir de uma situação paradigmática, que se repete na poesia drummondiana. Nela, "o poema se

Em 2015, o escritor Pierre Smolik lança o livro The Freak-Chaplin's Last Film, tentando investigar alguns aspectos do mistério que até hoje ronda este último projeto de Chaplin, pois ao longo de todo esse tempo nunca se esclareceu o motivo pelo qual o filme acabou não sendo concluído e por que a maior parte do material existente não veio a público. O que se sabe é que o projeto começou a ser realizado em 1969 e assim seguiu por dois anos: o roteiro foi finalizado e existem passagens de áudio de Charles Chaplin a ler o script; algumas faixas de música foram gravadas, inclusive o tema principal «You are the song» (melodia de Chaplin e letra de Glen Anthony); há cenas de Victoria, filha de Chaplin, então a protagonista do filme, já com o figurino (inclusive com as asas feitas de penas de cisne); footages estão listados no BFI National Archive; ensaios para os efeitos especiais foram realizados e storyboards chegaram a ser feitos.

5 Carlos Drummond de Andrade adota a versão "Carlito" para o original "Charlot", o que poderíamos aludir, com efeito, ao próprio alter-ego que cria a partir daquele personagem. 
fecha, como a linha de uma circunferência [...], que depois de percorrer outras áreas retorna sobre o ponto de partida, sem que, dubiamente, o trajeto e a experiência tenham contado, embora afinal eles contem" (Santiago 1966: 24). A linha de condução do seu poema geralmente se insinua reta no início e se revela circular no fim, como se organizasse as etapas de um ciclo vital que está inserido no círculo da vida. O que se sobressai é a evolução do símbolo em enigma, sempre um objeto que intercepta os passos do poeta, que então pára para investigar e refletir sobre o que se coloca à sua frente. Esse enigma obscuro "zomba da tentativa de interpretação", como diz Drummond em «O enigma», evocando o funcionamento retórico para se pensar a própria poesia, com toda a sua impossibilidade e a sua condição de não decifrável, como sustenta o oxímoro no próprio título daquela sua sétima obra, Claro Enigma. A irresolução não é um problema, é a solução. Por isso, mesmo ao ser subitamente interceptado por um objeto ao longo do percurso, por fim o poeta vai sempre seguir rente o seu caminho.

Diríamos, portanto, tendo em vista este poeta do impasse, do bloqueio, da interrupção, que estamos diante de uma poesia marcada pela impossibilidade de um destinatário e pelo bloqueio da possibilidade de leitura, ou que inviabiliza a forma de leitura programada no início. O que nos leva a pensar se Drummond não estaria, assim, tão "preso à pantomima", a que alude em «Canto ao homem do povo Charlie Chaplin», quanto está a versão do Chaplin que ele mais admira. O gesto de escrita do poeta, nesta perspectiva, não acabaria por pressupor um movimento pantomímico, ${ }^{6}$ uma vez que várias palavras vão sendo escritas na tentativa de se acertar $a$ palavra, e as palavras escritas nunca chegarão para dizê-la? O enigma não passa também por essa descrição que denuncia o indizível?

A natureza desse movimento, na qual a palavra é despoletada para reiterar a sua impossibilidade de leitura, parece ser, afinal, a catacrese. O mais curioso é que este mecanismo também é fundamental para o espaço de criação de Ruy Belo, assinalando "ao mesmo tempo a insuficiência da linguagem e a natureza da correcção", como evidencia Clara Rowland (2015: 260). Do mesmo modo, para Manuel Gusmão (2010: 415), a catacrese é um dos principais mecanismos desenvolvidos por aquele poeta que ao longo de sua obra vai tratar de "reconduzir o Próprio ao comum". A poesia beliana, de maneira insistente, ou mesmo incorrigivelmente, troca coisa por coisa, numa substituibilidade ou convertibilidade contínua, de modo que uma mesma palavra serve muitas vezes para falar de coisas diferentes (cf. ibid., ibid.). Assim, na obra poética de Ruy Belo, o poeta se inscreve na sua impossibilidade (o poema é uma tentativa de), enquanto na poesia de Carlos Drummond de Andrade o poema é que é escrito na sua impossibilidade (o poema é uma tentativa). "Tudo é possível, só eu impossível”, diz Drummond (1988: 50), em «Segredo», indicando uma poesia que viria ser capaz de circular sem poeta (cf. Saraiva 1989: 05). Quer dizer, esta poesia vai se tornando, como diria Manuel Bandeira, "pura poesia, profundamente", consequência, queremos crer, de uma obra exposta às tensões de uma existência conformada ao estado de catacrese.

Se recuperarmos o objeto carta, agora na poesia de Ruy Belo (2009: 306 e 307), assistiremos ao poeta que, "ao esperar uma carta", declara essa sua "incorrigível ma-

Recordemos os seguintes versos de Jorge de Lima, em Invenção de Orfeu, acentuando a natureza racional e, ao mesmo tempo, intuitiva do pantomimo, que tanto nesta poesia quanto na de Drummond pode ser visto como uma forma de aludir ao exercício de escrita poética: "Convictamente é tudo em potencial / [...] / Mímico racional. Ah! o pantomimo, / - esse intuitivo. [...]” (Lima 1958: 677). 
nia de trocar coisa por coisa / que faz com que eu repita a mesma palavra / para falar de realidades diferentes [...]". Talvez por isso mesmo Ruy Belo apresente o poema como «Estudo», sugerindo que todo poema é, na verdade, um "estudo" que resulta dessa "mania" superveniente de trocar coisa por coisa. O que fica patente quando ainda questiona: "Quantas vezes terei falado da morte pensando na carta / ou noutra qualquer forma de ameaça?". Aqui, o destinatário se confunde com o remetente, ao passo que "não é a carta a funcionar como figura da morte, e sim a morte a ser apresentada como figura da carta e de "qualquer outra forma de ameaça"” (Rowland 2015: 259). Se considerarmos que também para Drummond "pensar a ameaça não é removê-la; é criá-la", como diz ainda em «O enigma», a ameaça pode ser lida, então, tanto num como noutro poeta, como a criação daquele movimento catacrésico de compensação que resulta no poema que está desde logo ameaçado ao ser dito, porque condenado a ser outra coisa dentro em pouco, assinalando desde logo a condição irredutivelmente bilingue da linguagem.

O resultado é um poema que, apesar de dado por terminado, continua incompleto, inacabado, no qual os elementos se identificam para se diferenciarem ou se descaracterizarem. O jogo pantomímico, decerto, é motivado por um gesto catacrésico de criação, e o que poderia ser apenas mais um recurso se torna, enfim, condição de criação poética naquelas duas poesias.

\section{Morte secreta}

Se a natureza da catacrese é a mesma, em ambas as obras poéticas, então é preciso investigar agora se os efeitos provocados também são os mesmos. Não há dúvidas de que aqueles dois autores concebem a poesia como uma linguagem com um fim em si mesma. É na sua criação e consistência verbal que a poesia se afirma e se configura. Acontece, no entanto, que se a obra poética de Ruy Belo "provoca um pequeno sismo vivificante no senso comum da realidade" (cf. Belo 2002: 24), a mensagem poética, na poesia drummondiana, é uma "visão deformadora da realidade" (Teles 1970: 27). Por cingir muito de perto a realidade, Ruy Belo acaba por humanizá-la, enquanto Drummond, do alto de sua poesia cética e de sua reflexão crítica, e por mais humanidade que tenha o seu gesto poético, acaba sempre por lembrar que o homem é o obstáculo do universo. O autor de «Figura jacente», confrontando-se com a sua própria face, reconhece: "Meu rosto nasce desta condição horizontal" (Belo, 2009: 167), ao passo que o poeta de «Não se mate», num embate constante com a maneira como vê a si mesmo, e que se manifesta na luta com o seu próprio nome, admite: "Entretanto você caminha / melancólico e vertical" (Andrade 1988: 50). Como observa Júlia Studart,

Há no poeta brasileiro uma certa verticalização impositiva da ausência, do que não se sabe nem se pode saber, muito próximo de sua poesia ambivalente e filosoficamente vigorosa [...]. Em Ruy Belo, de outra maneira, há uma convicção estrita da horizontalidade a partir das coisas que continuam exatamente como estão e que se perdem no erro e na derrota do homem [...]. Tanto é que algumas das questões mais interessantes de toda a sua poesia são como sair da catástrofe, como escrever numa linguagem viva e "quanto mais poeta mais responsável" (Studart 2013: 08). 
Se atentarmos para a noção de "criador de palavras-realidades" de que fala Mário Faustino (2003: 212 e 213), em Ruy Belo prevalece uma "linguagem poética de criação", que tem por base uma linguagem mais sugestiva e reconstrutiva, tal como em Jorge de Lima, por exemplo, na qual sujeito e objeto se identificam numa enumeração recriadora ou numa sintaxe organizadora do caos. Já na obra do poeta mineiro há uma "linguagem poética de expressão", portanto mais aproximativa e metafórica (chegando inclusive à metáfora do próprio poema em formação), na qual o objeto é apresentado ao sujeito ou então a poesia "elide sujeito e objeto", como diz o próprio Drummond (1988: 96). Como recorda António Ramos Rosa, sobre o início da "poesia mais moderna",

[...] só Rimbaud e Mallarmé teriam a audácia de identificar [sujeito e objeto], inaugurando uma poética impessoal e objectiva. A partir de então o poema deixa de assinalar uma exterioridade para se constituir como criação autónoma em que a linguagem se torna independente e como que absoluta. [...] A distância entre sujeito e objecto aboliu-se: os objectos ganham um valor absoluto e, da mesma maneira, as palavras se tornam objectos absolutos (Rosa 1986: 44).

Aquele que é apontado como o principal autor da experiência moderna no Brasil ${ }^{7}$ nos faz perceber, com a justeza das palavras ao objeto expresso, que tudo ali "existe antes de mais nada como palavra" (Candido 2004: 92), reivindicando o importante legado de Mallarmé. Uma poesia-poesia ou poesia-para: "a consideração do poema como objeto de palavras" (Campos 2013: 53). Quer dizer, se há aquela narrativa da interrupção, é porque, em Drummond, "o pensamento se encarna - e se interrompe - na palavra" (Sterzi 2002: 85). É nessa ecologia que surge o acentuado valor estilístico da repetição de palavras como um dos seus principais processos expressivos, que, aliás, encoraja o raciocínio que viemos desenvolvendo desde o princípio: se a catacrese se torna condição de criação poética, podemos então afirmar que o mecanismo com que ela se manifesta na obra drummondiana é a repetição, explorada pelo autor de tal maneira que faz dele um caso bastante singular na literatura de língua portuguesa. Em Drummond - A Estilística da Repetição, Gilberto Mendonça Teles (1970: 186) chega à conclusão de que "tôda a poesia de CDA se projeta como resultado de uma luta contínua para exprimir mais e mais, sendo que a repetição parece ter origem nessa ânsia de superação do indizível". Ora, não poderíamos dizer que é exatamente a essa "ânsia" que atende a modulação de uma poesia em estado de catacrese? Tanto é que a repetição "comunica a mesma informação mais do que uma única vez e, eventualmente, de modos diferentes" (idem: 183).

Neste caso, o poema se abre a todo tipo de pesquisa, incorporando novos valores e significados, fragmentando a sintaxe, montando ou desarticulando vocábulos, praticando a linguagem reduzida. O poeta sabe que poderia dizer muito além das palavras, tanto quanto sabe que estará sempre a elas condicionado.

Repetindo a mesma palavra, está criando outro vocábulo, um vocábulo bem maior de que a língua não dispõe nos dicionários (embora o pré-disponha nas suas estruturas), conseguindo portanto outras fôrças de sugestão e estabelecendo também associações misteriosas e estranhos apelos, além de fugir a uma pretensa riqueza

O crítico Tristão de Athayde (1969), no ensaio «O Poeta Brinca», chega mesmo a considerar Carlos Drummond de Andrade "uma espécie de Baudelaire da nossa poesia moderna". 
lexical e sinonímica, mais diluidora que intensificadora da linguagem poética (Teles 1970: 183).

Assim, numa poesia em estado de catacrese, que se reverbera na exploração dos mais distintos tipos de repetição e que fia a sua metalinguagem partindo sempre da palavra, diríamos que seria inevitável recair sobre outra problemática anunciada pela "voz dispersa" do poeta: "manténs vivas as coisas / nomeadas" (Andrade 1988: 301), como lemos no poema «A palavra e a terra». A poesia seria, no seu núcleo mais elementar, as coisas nomeadas pelo poeta, na condição de saber que "O nome é bem mais do que nome: o além-da-coisa, / coisa livre de coisa, circulando" (idem: 302). Aqui já estamos no décimo livro de Carlos Drummond de Andrade, que elege, logo a partir do título, a problemática que lhe fez valer a alcunha de "Drummond, mestre de coisas", conforme intitulou Haroldo de Campos uma crítica que escreveu sobre Lição de Coisas. ${ }^{8}$ É com este livro que "Drummond atinge o mais puro fio de sua filosofia existencial e estética" (Teles 1970: 181), em se tratando de uma obra na qual vai largamente explorar a relação entre o poeta e a confiança que imprime no nome ("Tudo é seu, que enuncias", diz também em "A palavra e a terra»), revendo inclusive o caminho que até então percorrera, em que muitas coisas "feneceram em sigilo", como acusa naquele mesmo poema.

Do mesmo modo, na poesia de Ruy Belo, essa problemática "palavra - nome - coisa" também é uma constante, gerada e fomentada pelo mesmo espaço em catacrese e sob o efeito da repetição, outro dos seus notáveis traços estilísticos. A anáfora se destaca nesse processo, como podemos ver, por exemplo, no poema «Um quarto as coisas a cabeça».

E ter eu de passar a vida à procura da chave

e procurar abrir e não saber da chave

e não existir nunca porta ou chave

e chave ser palavra ambígua ter sentido

e haver muitas palavras e muitíssimos sentidos

e a vida ser só uma e ser a vida

e haver mãos para as coisas gestos para as mãos

e não haver que porra uma saída

E esta cara esta cabeça susceptível de ser vista

e tudo quanto faço interpretado e comentado

e haver nomes e eu ser isto e não aquilo

e eu sentir-me em nomes encerrado

Quero dormir não ter esta doença de pensar

estender-me sob o céu o mais possível ao comprido

e que bastante terra cubra o meu comprido corpo

e eu seja terra apenas e a terra nada seja

(Belo 2009: 468; itálico nosso)

8 É interessante observar que no seu exemplar de Baudelaire-Par lui-même, de Pascal Pia, Ruy Belo vai associar a "Drummond", como escreve na marginália, a expressão "leçons de choses", que Baudelaire previa como título para um álbum de pintura, como se vê na passagem assinalada: "Il avait également dessiné tout un album de 'leçons de choses' dont, sexagénaire, il se servait pour illustrer les premiers éléments de latin qu'il s'efforçait d'inculquer à son petit garçon” (Pia 1959: 12). 
Afinal, esse nada, em Ruy Belo, que aparece frequentemente em sua poesia, quer nos parecer originário da mesma matéria que o nada invocado por Drummond, que desde o início de sua obra declara: "Minha matéria é o nada", diz em «Mãos dadas». Podemos assumir, desse modo, que o "flerte com o nada pode ser um flerte com a morte, de que nada é eufemismo", denunciando a "afinidade com o mundo dos mortos que Drummond [e também Ruy Belo, incluiríamos] está sempre a confessar" (Sterzi 2002: 69). Naquelas duas obras, a poesia é uma espécie de "morte secreta" (Andrade 1988: 204), pelo que os dois poetas podem ser vistos como "Poeta[s] do finito e da matéria” (idem: 94). Recordemos quando Manuel Gusmão (2010: 416), ainda comentando sobre os efeitos da catacrese na poesia de Ruy Belo, anuncia que há ali "coisas de um mundo finito que a poesia pode entretanto ilimitar sem, para tal, precisar de pressupor uma transcendência originária ou essencial". No caso da poesia de Drummond, há de se iludir, como afirma Sérgio Buarque de Holanda (1996: 502), quem nela vê uma "poesia entendida como essência inefável, contraposta ao mundo das coisas fugazes e finitas". Talvez possamos mesmo dizer que em ambos os autores a adesão a uma poesia participativa não chegaria neles a abolir "a preocupação constante do mundo finito e das coisas do tempo" (ibid.).

Esse nada, associado àquela "morte secreta", leva-nos à "poesia mais caracteristicamente moderna", para utilizarmos a expressão de António Ramos Rosa (1986), em que a única realidade passa a ser a própria linguagem, a partir da destituição da sua natureza funcional, que privilegiava a comunicação, e da destruição da categoria do real. Assim, "as palavras já não obedecem às relações gramaticais, mas condensam em si as múltiplas virtualidades significativas" (idem: 45). A partir de Mallarmé, "é a própria ausência do objecto que se pretende dar", e por isso passamos a estar diante da "ontologia do nada", em que "o nada é a verdade" e o poeta profere "a palavra para volver e fundi-la na sua inanidade, desvinculando-a de todo o seu significado para passar a ser apenas a expressão do silêncio e do nada, uma pura vibração" (cf. ibid.). A noção de significação, que se esgotava na visão monocular ou numa perspectiva única, é preterida pela infinita potencialidade da linguagem, pautada por uma "pura liberdade criadora", de modo que o conteúdo do poema deixou de depender do assunto ou do argumento que o estruturava. A poesia não se configura mais como a arte do objeto, mas do nome do objeto, somente desse modo podendo constituir uma nova realidade. Por isso, para o autor de Poesia, Liberdade Livre, a arte moderna "nasceu de um movimento íntimo de reacção contra a hegemonia dos falsos valores que pretendem reger o mundo e que, de facto, ainda o comprimem e o sufocam" (idem: 47).

Para Gilberto Mendonça Teles, esse movimento de profunda liberdade

se, por um lado, podemos dizer que tem sido sempre a vitória estética da energia criadora do homem sobre as estruturas da língua, por outro, não se pode ignorar que se trata de uma vitória incompleta, uma vez que grande parte da vitalidade de seu mundo poético deve ter continuado prêsa, sufocada na garganta [...] . O próprio Drummond - que sempre introduz modificações em seus poemas - não esconde o seu pessimismo diante dos problemas expressivos e, noutro indício de modernidade, possui em todos os livros poemas cujo conteúdo é a representação de uma concepção poética ou poemática, ou a referência angustiosa à luta pela expressão (Teles 1970: 179). 
Podemos observar essa "luta pela expressão", em Drummond, situando a temporalidade da sua leitura, a propósito de Roland Barthes (1987), entre o "clássico" e o "moderno". Digamos que a poesia drummondiana vive entre o regime confortável da leitura e a exigência de produtividade da leitura. Do texto clássico, apresenta a fluência, a agilidade, o baixo grau de resistência; do texto moderno, a eficácia, a capacidade de estar aberto a um plural ilimitado. É nesse sentido que essa obra poética proporciona uma leitura próxima e, ao mesmo tempo, evoca o distanciamento necessário para que o desencadeamento de significantes resulte em um texto concentrado, mas que dilata a leitura. Os textos clássicos, segundo o autor de $O$ Prazer do Texto, têm uma origem ambivalente ou polissêmica, desdobrando-se a partir da multiplicação justaposta de sentidos, enquanto os textos modernos, porque a significação não é dada, não oferecem imediatamente o sentido, o leitor é que vai optando a todo tempo pelo sentido do texto, que não apresenta referências estáveis. Enquanto um intensifica a parte do sentido posto, o outro, portanto, radicaliza a parte do sentido retirado (cf. Bosco 2004). Não por acaso, ressalva ainda Ramos Rosa (1986: 47) que "a significação de um poema especificamente moderno depende tanto dele quanto de nós e é precisamente desta colaboração profunda entre criador e leitor que uma significação pode surgir e actualizar-se. Daí o fascínio particular que o poema exerce".

A poesia de Drummond, portanto, amplia ao máximo o sentido sem rompê-lo, pluralizando, sutilizando, complexificando, embora sem prescindir do sentido ou excluir o sentido de unidade, valendo-se do equilíbrio a partir de uma zona de tensão elíptica. Naquela obra, há a manutenção de uma "economia racional", que Barthes associa à "transparência clássica", atribuindo-lhe um valor aporético: "ela é ao mesmo tempo aquilo sobre o que não há nada a dizer, e aquilo sobre o que há o máximo a dizer" (Barthes apud Bosco 2004: 47). Para Silviano Santiago, Drummond não é desde o início um clássico, ele vai se tornando um clássico, e claro está, a linguagem clássica é tida, aos olhos de Barthes, mais como uma arte de expressão do que de invenção, organizada em função de uma linha contínua de significações que integra uma estrutura narrativa.

Drummond aspirou a ser um clássico só depois de ter atingido a idade madura, outonal [...]. Ser clássico não é uma atitude artística, mas uma atitude existencial. Esboça-se aqui a diferença essencial entre a sua obra madura e a geração de 45 . Ele queria domar uma explosão dentro da sua própria poesia, da sua poesia passada, enquanto os outros freavam uma fase anterior da poesia e começavam a sua obra com uma atitude pensada, medida, clássica (Santiago 1966: 18).

A passagem do símbolo para enigma, nesse trajeto em que supostamente Drummond "domaria uma explosão dentro da sua própria poesia", pode ser vista ainda como outro indício dos efeitos autorreflexivos provocados por uma poesia que está, ao fim e ao cabo, sempre em busca de outra poesia, ou que constantemente se desmente ao trocar coisa por coisa. A continuidade ontológica entre formas diversas, afinal, resulta numa poesia que se desenvolve por metamorfose, ${ }^{9}$ à qual podemos associar a mimese progressiva: "o poeta sabe que a vida não se repete (ou que não

" Não nos referimos, neste caso, a uma "metamorfose de linguagem" própria da poesia, da sua propriedade de distorcer a linguagem cotidiana. A metamorfose aqui é um esquema lógico utilizado para se pensar como uma coisa se torna outra coisa na poesia de Drummond, dentro dos próprios limites da linguagem poética. 
passa tudo de repetição, na velha forma Eclesiastes), e que a arte deve ser compreendida como uma mimese progressiva, porquanto o artista está sempre deformando o real" (Teles 1970: 35). Nessa deformação do real, portanto, a metamorfose, em Drummond, manifesta a tendência à correção do olhar ou da nomeação (cf. Sterzi 2002: 84). O nome, em certa medida, está subordinado à palavra: nomear é uma tentativa de encontrar a palavra. Essa tentativa implica, ainda, que metamorfosear seja também sintoma de nomear, na justa medida em que tanto um como o outro representam uma ruptura com os constrangimentos das leis da natureza, com as correspondances, como diria Baudelaire.

\title{
3. E de repente, a porta ou a chave
}

Neste sentido, se retomarmos o poema «A palavra e a terra»,

\author{
se a essência \\ é o nome, segredo egípcio que recolho \\ para gerir o mundo no meu verso? \\ para viver eu mesmo de palavra? \\ para vos ressuscitar a todos, mortos \\ esvaídos no espaço, nos compêndios? \\ (Andrade 1988: 301)
}

veremos que o nome é um "segredo egípcio" que, na sua condição hieroglífica, exige que se procure desvendá-lo ou decifrá-lo, o que revela mais um gesto catacrésico daquela poesia. A escrita egípcia, ideográfica, não tenta representar a imagem real das coisas, como a pictografia, mas sugere o seu nome, entendido, então, como uma forma de tornar presente o mundo dos mortos, de "tocar" o mundo dos mortos. Basta lembrarmos que o Livro dos Mortos orientava o destino dos que morriam, mostrando como fazer para se atingir a imortalidade no reino de Osíris, após um julgamento que girava em torno da palavra, que deveria servir, desse modo, para provar a justiça praticada sobre a terra. Desse julgamento, nem o grandioso deus Rá, deus do sol, poderia fugir.

Agora reparemos que, se em Drummond, esse segredo vai sempre culminar na forma como a palavra funda e gere o mundo (não por acaso «A palavra e a terra» é o primeiro poema de Lição de Coisas, na parte intitulada «Origem»), em Ruy Belo chegamos mesmo a presenciar encenações desse momento fundador, como se observa em «Em cima de meus dias»:

Muita gente me tem falado a meu respeito como quem me chamasse pelo nome e eu me voltasse e nesse nome dito nessa boca fosse toda a minha vida e eu morresse quando entre pinhais quem me chamara a fechasse (Belo 2009: 195)

Nesta primeira estrofe, prontamente se anuncia aquela "morte secreta" de que falávamos. Essa grande boca de deus, que continha a palavra, fecha-se, tal como em 
«Última vontade», de Aquele Grande Rio Eufrates ("Fechem-se-te agora os lábios / sobre a palavra que somos"). Ruy Belo encena aqui a morte de deus, ${ }^{10}$ sendo esta, aliás, uma daquelas «Sete coisas verdadeiras» que enumera na seção assim intitulada, da qual justamente «Em cima de meus dias» é o primeiro poema, em Boca Bilingue. Está declarada, dessa maneira, a condição irredutivelmente bilingue da linguagem, que prevê que mesmo que o homem esteja condenado a tentar alcançar a palavra original, tudo o que disser será irremediavelmente outra coisa já. Notemos que logo depois de anunciar aquela boca que se fecha (ou a morte de deus), o poeta assume que "Ninguém sabe o meu nome", e mais adiante revela: "E sabem mesmo que o meu nome é Rá". O poeta, privilegiado pela consciência de seu bilinguismo "Bilingue é toda a poesia" (Belo 2002: 31) -, ocupou o lugar de deus. Teria sido Rá, com toda a sua divindade solar, no Antigo Egito, segundo uma das versões do mito, que criara todas as formas de vida, chamando-as à existência ao pronunciar os seus nomes secretos. De modo que o "segredo egípcio", que acaba em palavra na "turva sintaxe", de Drummond, é o "Precário, provisório nome" (Belo 2009: 212) do poeta, em Ruy Belo.

[...] se esta obra parece desejar uma boca unívoca, qual seria a de Deus - "ó Deus, ó mais redonda boca para o nome das coisas” («Efeitos Secundários») -, ela acaba por se ver confrontada com a inapelável irrisão da linguagem dos homens: "És aquele que no maior número possível de palavras nada disse” («Relatório e Contas») (Silvestre 1997: 20).

Com o passar do tempo, observamos na poesia beliana um desinvestimento na própria omnipotência criativa de deus, que é o mesmo que dizer de um sujeito poético que vai deixar de emular a unicidade do verbo divino, à medida que tenta se convencer da morte de deus. Sendo a univocidade linguística um privilégio sagrado, o poeta é já o deus Rá, aquele que assume, então, o ato criador. Segundo Pedro Serra (cf. 2003: 75-84), o poeta deixa de perspectivar a origem da nomeação dos seres e das coisas em deus e de concebê-lo como Verbo (Único), de modo que não é mais sua obrigação a multiplicação da Palavra em palavras. O sentido agora é outro: as palavras se multiplicam em palavras, trocando coisa por coisa, numa poesia que vai denunciar essas mudanças com o alongamento do verso e do poema, assumindo o estatuto de deambulatória como uma conquista da sua modernidade. Como desvanece o compromisso de tentar alcançar a palavra de deus, também sem um rumo determinado se encontra o poeta. O resultado é paradoxal: "é como se a perda de deus levasse os versos a serem repetição infinita da perda de sentido; e como se essa perda, infinitamente repetida, gerasse afinal a forma discursiva que dá sentido a essa repetição - ou seja, a poesia" (Martelo 2012: 164).

Afinal, se em Carlos Drummond de Andrade a repetição se revela na microestrutura - "dizer além da palavra, mas através dela mesma, repetindo-a, amplificando-a, fazendo-a vibrar em consonância com outras, e preferindo desdobrá-la a substituí-la por um sinônimo incapaz de traduzir a sua obsessão interior" (Teles 1970: 97) -, o gesto catacrésico beliano, em direção a "uma poesia after word", ou "a busca do poema para além do poema" (Serra 2003: 83), revela-se desde a macroestrutura, a partir

10 Não é Ruy Belo quem vai dizer: "Sou um profissional de mortes [...]. E pronto. Senão fico sem história, sem Deus, sem homem" (Belo 2002: 41). 
do que podemos chamar de uma "poética do excesso". Ao estimular a repetição, ela acaba sendo fomentada, conforme ainda sugere Pedro Serra, pelo "princípio de emagrecimento", em que a racionalidade de uma economia vocabular é resultado do fracasso da nomeação: "a nomeação falhada não garante a ontologização do 'vazio' originário" (Serra 2003: 84). Desse modo, a perda de deus, que faz com que os versos sejam aquela repetição infinita da perda de sentido, pode ser concebida como a engrenagem de uma poesia de poucas palavras. O poeta, sem o seu pré-suposto rumo, sabe que o excesso de palavras conduz, paradoxalmente, à palavra que nunca poderá ser alcançada: "És aquele que no maior número possível de palavras nada disse", como afirma em «Relatório e contas», ou o "homem que afinal só fala por falar", apoiado em apenas "três palavras" (Belo 2009: 217 e 467), como diz ainda em «Um quarto as coisas a cabeça». Por isso, num livro como Toda a Terra, reiterando um percurso poético que assenta na consciência da perda de um "Nome Único", o poeta chega à conclusão de que: "vi-me verbo do meu nome / inalterável indelével e impassível" (idem: 690), quer dizer, senhor da sua própria palavra, em que o verbo age agora sobre o nome, acabando por torná-lo fixo na sua provisoriedade.

O modo como uma "religiosidade torturada" vai transformando a relação de Ruy Belo com um deus cristão modifica também, pouco a pouco, o seu gesto criador: se em Homem de Palavra[s], como vimos, o poeta sustenta a sua "incorrigível mania de trocar coisa por coisa”, em Toda a Terra a dimensão das inquietações é já outra, num poeta mais cansado e, por isso mesmo, mais resoluto: "Como dizer-te que não há coisas por detrás das coisas?" (idem: 727), questiona como quem afirma que a "morte secreta" é a morte absoluta, do corpo que regressa à terra, cumprindo o seu ciclo de retorno à natureza. «A força das coisas» reside precisamente naquele "súbito desejo de ficar na noite / dormindo o sono íntimo da terra" (idem: 383), ao se saber que todas as coisas se reencontram, afinal, porque são feitas da mesma matéria e acabam por se integrar antes e depois da vida - por isso, a vida poderia ser vista como o grande intervalo instaurado na morte. Desse modo, a própria morte, na sua distensão máxima, seria regida pelo princípio catacrésico, e não passaria da troca de coisa por coisa. Como propõe Eduardo Lourenço,

Tudo se passa como se um anjo improvável tivesse guiado a sua barca luminosa entre os destroços infernais da Modernidade - como num filme de Bergman às avessas - e o tivesse trazido, com toda a consciência disso, para outra Modernidade, modernidade sem ressentimento, aceitando a morte de Deus como uma outra espécie de iniciação e não glosa interminável do desespero (Lourenço 2002: 216).

Assim, diríamos que enquanto Ruy Belo constrói a sua modernidade enunciando continuamente essa morte de deus, que então reforça o mistério da vida, em Drummond, o mistério da vida não reitera o mistério de deus: naquela poesia, deus já nasceu morto, ou pelo menos ausente.

Você não pode imaginar como Deus me chateia. Eu não creio nele. [...] Não é Deus que é misterioso; é a vida que é misteriosa. Por que nós nascemos? Por que alguém nasceu e gerou outros tantos? Esse mistério não está explicado, e eu me curvo diante dele. Agora, não aceito uma explicação metafísica. A única coisa de que estou convencido é de que nós morremos de verdade, nós morremos mortos. [...] E aí vem o problema da morte. A aceitação da morte é o máximo que o ser pode conseguir para 
efeito de se ajustar com a vida, de se entender com a natureza. Se todas as coisas são mortais, o homem não pode pretender à imortalidade (Andrade 2002: s/p).

Este poeta se reconhece no "tempo em que não se diz mais: meu Deus", ou que sabe que "Jesus já cansado de tanto pedido / dorme sonhando com outra humanidade" (Andrade 1988: 67 e 35). As limitações humanas, ou a deformação dos indivíduos, desfiguram o próprio deus, que parece não existir em meio a tantos absurdos - o que pode ser visto, inclusive, na economia de meios daquela poesia, representando a própria escassez da realidade. Por isso, a obra poética de Drummond, que tão bem soube praticar a violação e a desintegração da palavra, consegue muitas vezes aparentar a ausência de artifício literário, num "prosaísmo cru" (cf. Cruz 2008: 377) que intensifica o poético pela força do contraste ou prevê a criação de lirismo pelo impacto de formas não-líricas. Existe mesmo a recusa, no limite, de certas medidas e acentuações reconhecíveis do verso ou a quase rejeição do próprio ritmo, naquele poeta que soube cultivar desde a forma fixa "ao verso que tem apenas a medida e o impulso determinados pela coisa poética a exprimir" (cf. Coutinho 1967: 27). De modo que os caminhos formais escolhidos também manifestam aquele lugar vazio de deus, que vai sendo preenchido pelo amor resiliente e solidário ao sofrimento humano, e pela compaixão que desmilitariza o olhar diante dos humilhados e olvidados pela sociedade, num cenário marcado pela "antinomia entre o Homem e o Mundo".

Antinomia, aliás, que João Gaspar Simões (1999: 447) diz não detectar no primeiro livro de Ruy Belo, ao passo que vai ainda argumentar: "na sua poesia confundem-se inextricavelmente todos os elementos presentes no Mundo. O próprio Deus 'olha finitamente a sua obra' pelos olhos da criatura" (idem: 447 e 448; itálico nosso). Ora, é aqui onde questionamos: não seria exatamente esse ato de "confundir inextricavelmente todos os elementos presentes no Mundo" um indício de que existe o que poderíamos chamar de motor catacrésico desde o início daquela poesia? Não se revela, desta forma, um poeta para o qual deus vai se tornar cada vez mais humano, um poeta que vai se assumir mais crente no homem do que em deus? Não nos parece que o delineado movimento em catacrese resulte de um poeta que, tomado pelo desengano diante da inelutável transitoriedade da vida e da precariedade do mundo, tente a todo custo preencher aquele "lugar deixado vazio"? O sujeito poético, portanto, consciente de que a palavra divina já não coincide com o mundo, compreende que as suas palavras serão sempre imperfeitas, e admite, assim, a fratura delas com o mundo. Se as palavras mediatizam a relação com o mundo, à partida ele já se torna inalcançável, e na impossibilidade de obliterar o real, o que fica é a consciência do poeta de que não se pode devolver esse sentido íntimo do mundo (cf. Serra 2003: 81 e 82).

Em um poeta que está constantemente a afirmar "Sempre entre mim e ao que chamam coisas há-de haver palavras", como lemos em «Um quarto as coisas a cabeça», a própria noção de chave poética não poderia deixar de ser recursiva, conforme observamos neste mesmo poema:

E ter eu de passar a vida à procura da chave e procurar abrir e não saber da chave e não existir nunca porta ou chave e chave ser palavra ambígua ter sentido e haver muitas palavras e muitíssimos sentidos (Belo 2009: 468) 
Essa metáfora alusiva a um sujeito poético que sabe que está condenado a tentar encontrar $a$ palavra, e que do mesmo modo sabe que não irá encontrá-la, também persiste em Carlos Drummond de Andrade (1988: 97), que desde logo avisa que a pergunta é retórica, sem interesse de resposta: "Trouxeste a chave?", indaga em «Procura da Poesia». "E perguntar será para ti responder", como diria Ruy Belo (2009: 213). Se na poesia beliana o problema da habitação será sempre não haver mais habitação, casa onde habitar, e por isso, como vimos no excerto acima, não existe "nunca porta ou chave", para Drummond (1988: 1012), não obstante, o problema da habitação se configura como um "interior desabitado", onde "dentro em nós [é] que as coisas são, / ferro em brasa - o ferro de uma chave". Afinal, neste poema, «A chave», da fase final do autor, encontramos uma espécie de súmula da sua poesia: "E de repente / o resumo de tudo é uma chave. // A chave de uma porta que não abre / para o interior desabitado", lemos no início. Perguntar é um exercício de repetição meramente retórico porque a "porta [é] sem fechadura", tal como a "esperança é a palavra que a vida não alcança" (idem: 1011), como já assegurava o poeta trinta anos antes, em «Viver».

Desse modo, prescindir da chave não tem a ver com o sentimento de renúncia à intervenção poética na realidade, mas sim com a consciência de que "os instrumentos fracassam frente à complexidade e à inapreensibilidade do real" (Sterzi 2002: 58). Quer dizer, "o movimento do poeta em direção à realidade é um movimento essencialmente frustrado, impedido não apenas pela dificuldade ou impossibilidade de apreensão do real [...], mas sobretudo pelo imperativo ético de não escamotear essa inapreensibilidade, ou, antes, de expô-la às claras" (idem: 64). Além disso, o nunca achar a chave por não haver chave parece estar vinculado àquele manancial de plurissignificações instaurado pela modernidade, com a multiplicidade dos pontos de vista. Se a aventura da liberdade criadora já não se limita ao Criador, da mesma forma já não se limita ao criador enquanto poeta ou artista. "Estende-se agora a todos os homens, pois que é de cada um de nós que dependem os possíveis significados que pudermos ou soubermos extrair da obra que lermos, ouvirmos ou contemplarmos" (Rosa 1986: 46 e 47). Como sabemos, na modernidade, o leitor, ao experimentar uma série de possibilidades, passa a ter também uma "chave", "uma intuição recriadora que o leve a identificar-se com o poema, aproximando-se o mais possível do ato criador" (Teles 1970: 181).

\section{José e o boi contraditório}

Podemos sem prejuízo dizer, nesse sentido, que a condição de uma escrita em estado de catacrese, essa "mudez desatada na linguagem", como o poeta diz ainda em «A Chave», se desponta em tais autores em razão de suas afiançadas modernidades, a bem dizer, aponta também para uma humanidade marcada pela perda do nome, pelo anonimato. É a esta observação que o gesto catacrésico nos leva, com essa troca de coisa por coisa que se transforma em busca e, consequentemente, no próprio espaço de criação da escrita. Basta lembrarmos um poema, de Drummond (1988: 88), como «José», em que esse anônimo-com-nome tem a chave na mão e quer abrir a porta, mas a porta não existe (Com a chave na mão / quer abrir a porta, / não existe porta) e que desde o início questiona: "você que é sem nome, / que zomba dos outros, / você 
que faz versos, / que ama, protesta? / e agora, José?". Esse canto de José também está presente no poema de Ruy Belo «José o homem dos sonhos», tornando-se um canto geral porque é, ao mesmo tempo, profundamente particular. José é visto como poeta, e o poeta se assume como José. Assim, vemos mais uma vez a problemática do nome surgir como eixo fundador do poema.

Que nome dar ao poeta

esse ser dos espantos medonhos?

Um só encontro próprio e justo:

o de josé o homem dos sonhos

Eu canto os pássaros e as árvores

Mas uns e outros nos versos ponho-os

Quem é que canta sem condição?

É josé o homem dos sonhos

Deus põe e o homem dispõe

$E$ aquele que ao longo da vereda vem

homem sem pai e sem mãe

homem a quem a própria dor não dói

bíblico no nome e a comer medronhos

só pode ser josé o homem dos sonhos

(Belo 2009: 334)

É interessante observar que este poema faz parte do livro Homem de Palavra[s], precisamente aquele em que o poeta passa a assumir de maneira mais resoluta um deus que "como um homem se deita como um homem se levanta" (Belo 2009: 321), um deus - parafraseando Ruy Belo - que se tornou a mais redonda boca para o homem do homem. Assim, parece haver em «José o homem dos sonhos» um núcleo simbólico possível de se reconhecer também no poema de Drummond. Do José bíblico, nome de vários personagens importantes do livro sagrado, ao José nome popular, nome de homem comum, que de tão comum não dificilmente representa a perda de individualidade. O Zé. O Zé da esquina, o Zé ninguém, o Zé mané. "homem sem pai e sem mãe", como diz Ruy Belo. O José por ele criado, senão "o homem dos sonhos", não deixa de ser uma resposta, um tanto esperançada, queremos crer, ao José de Drummond, para o qual "tudo acabou / e tudo fugiu / e tudo mofou". Se ambos marcham sem saber para onde, a verdade é que um e outro continuam a cantar mesmo sem condição, como o próprio sujeito poético de «José o homem dos sonhos» se mostra consciente. Segundo Affonso Romano Sant'anna, numa análise que podemos distender àqueles dois "Josés",

José está a meio caminho entre o poeta e o leitor. Principalmente, José não tem lastro familiar. Não tem sobrenome, não de sabe de onde veio nem para onde vai. [...] Suas alternativas não passam de hipóteses seguidas de reticências. Até a morte lhe é estranha. José é essencialmente o ser aporético. É uma espécie de zero à esquerda, símbolo de uma era de massificação, época de objetos e não de sujeitos (Sant'anna 1972: 57). 
José - que dá título ao quarto livro de Carlos Drummond de Andrade - encarna esse homem moderno, acuado na multidão, na qual se vê sempre sozinho. Todas as expressões negativas presentes no poema ("Está sem mulher, / está sem discurso, / está sem carinho"; "o dia não veio, / o bonde não veio, / o riso não veio") acabam por ser uma forma de negar a sua própria "vida funcionária", que reduz o sujeito a relatórios e contas, a fichas e cadastros, a compromissos profissionais e vida doméstica. Nesse mundo burocratizado, em que estamos sendo sempre despersonificados por um paradoxal processo de customização, "Somos todos funcionários", como afirma Drummond, em «Canção Funcionária Mineira». Tal mote temático é recuperado por Ruy Belo e largamente explorado ao longo de toda a sua obra. Em «Relatório e contas», por exemplo, assume: "Podes tentar ainda alguns expedientes respeitáveis / multiplicar diversas diligências nos ameaçados cumes dos outeiros / ser e não ser fugir do rótulo aceitar e esquivar o nome fixo" (Belo 2009: 217). Já em «Ácidos e óxidos», também de Boca Bilingue, o poeta (que já no título parece sugerir uma certa vida corrosiva) vai anunciando inevitáveis "formas de morrermos dia a dia / como quem cumpre escrupulosamente o seu horário de trabalho" (idem: 211). Na «Meditação anciã», de Toda a Terra, o tema regressa como "esta gente que regressa nos seus carros / à cidade na tarde de domingo / Toda essa gente tem mulher e filhos / tem um emprego à espera tem vizinhos / um pôr do sol de que lhes serviria?" (idem: 722).

Esse mesmo incômodo do poeta, face a uma vida alienada, que não contempla o exercício de ver (do qual o "pôr do sol", naquele verso, é metônimo), pode também ser observado em «O Boi», outro poema do livro José. Aqui, a figura do boi expressa notavelmente esse desajuste do poeta com o mundo, dado que o sujeito poético se sabe consciente de que as principais práticas da poesia estão ameaçadas: o ruminar do pensamento, a paciência que dilata o tempo, o tempo para ver as coisas são prescindidos por uma vida exigentemente veloz, descartável, obsolescente. Conhecido por toda a simbologia associada ao rebanho, o boi aparece sempre sozinho - como ainda dá conta outro poema de Drummond, «Um boi vê os homens»-, encurralado na sua solidão, naquele "modernismo antipastoral" de que fala Baudelaire, entendendo que o dito progresso leva à decadência. Se o "Boi morto» de Bandeira, com o seu hermetismo, já se encontrava "Entre destroços do presente", «O Boi» criado por Drummond (1988: 79) parece constatar o estilhaçamento da identidade pessoal nas grandes cidades modernas: "Ó solidão do boi no campo, / ó solidão do homem na rua! / Entre carros, trens, telefones, / entre gritos, o ermo profundo". Como se sabe, o boi simboliza a calma e a força pacificadora, a capacidade de trabalho e o sacrifício, o que pode mesmo, naquele poema, apontar para esse mundo moderno de conciliações necessárias à existência de um homem sacrificado, refém do desejo de mudança e do terror que essa mudança possa vir a provocar.

O mais interessante é que o boi tanto pode representar o poeta, que se sente solitário, distante dessa multidão na qual se insere - e que de alguma forma ainda vê no campo o refúgio diante do caos que associa à cidade -, como também pode ser a representação de qualquer homem que, nos choques e estranhezas constantes provocados por essa vida urbana, desaparece na multidão e se torna apático diante do mundo, naturalizando a pobreza, a violência e a precariedade, tornando-as óbvios invisíveis. O homem moderno não conseguiria ter momentos de "calma e deleite" e mais pareceria uma anomalia da natureza, incapaz de viver em comunhão com ela, aos olhos do boi que o observa tranquilamente da sua pastagem, sem problemas (cf. Candido 2004: 69). A questão fulcral, entretanto, é que o poeta não deixaria de 
ser, na mesma, esse homem, o que nos leva à contradição fundadora e dialética do movimento crítico da modernidade, que sobrevive porque se autodestrói, que critica porque é crítica de si mesma, que é moderna porque profundamente antimoderna. Esse boi avança como símbolo de tudo o que a cidade não é porque justamente também a encarna - afinal, a sua solidão equivale à solidão do homem, essa solidão tão vasta que nem os mais novos aparatos modernos de comunicação e de transporte conseguem atenuar ("carros, trens, telefones").

É esse boi contraditório, como o é a própria modernidade, que Ruy Belo evoca em um de seus poemas de Toda a Terra. Ao falar de uma "noite negra caótica", o poeta clama: "ó boi ápio do ópio que me dói num arrepio / tenho no movimento o meu sustento" (Belo 2009: 691). Nesse jogo lúdico de significantes, "ó boi” lembra o chamamento que os intervenientes de uma tourada fazem ao boi, encarando-o - o que nos faz recordar, por um lado, de um verso como "Ó boi negro entre as capas vermelhas!", na «Lusitânia no Bairro Latino 1», de António Nobre, ou noutro viés, do poema «O boi da paciência», de António Ramos Rosa, notadamente um dos poetas portugueses que mais dialogou com a obra drummondiana. "Ó boi da paciência que fazes tu aqui?", repete algumas vezes Ramos Rosa (1997: 11-14), "cansado de recomeçar", naquele mundo em que "A fadiga substituiu-lhe o coração" e no qual se torna "familiar do absurdo". Ao encarar esse mundo, "que me dói num arrepio", como diria então Ruy Belo, é que o poeta confessa: "Hoje sou funcionário público. / Itabira é apenas uma fotografia na parede. / Mas como dói!", nas palavras de Drummond (1988: 57).

Além do mais, há sempre nesse mundo uma "bovina normalidade da vida familiar", como afirma ainda Ruy Belo (2009: 795), noutro poema de Toda a Terra, referindo-se à "incorrigível paciência" de quem consegue suportar aquela vida regida pelas modelações normativas da sociedade, que na altura salazarista era mesmo sustentada pela ideia de "Deus, Pátria, Família". É notável a forma como se dedica à ideia de que

Numa sociedade onde quase todos, pertencentes a quase todos os sectores, procuram afinal instalar-se o mais cedo possível, permanecer fiéis à imagem que se si próprios criaram pessoalmente ou por interpostas pessoas, o poeta denuncia-se e denuncia, introduz a intranquilidade nas consciências, na ordem pública, nas organizações patrióticas ou nas patrióticas organizações (Belo 2009: 367).

Neste mesmo texto, que serve de introdução a Transporte no Tempo, o poeta vai também dizer: "Altero uma ordem, uma harmonia, uma paz que, mais do que a paz invocada como instrumento de opressão, mais que a paz dos cemitérios, é a paz, a harmonia das repartições públicas, dos desfiles militares, da concórdia doméstica, das instituições de benemerência" (Belo 2009: 367). É neste livro, a propósito, que se encontra o poema «Um quarto as coisas a cabeça», que há pouco citamos, em razão de sua construção anafórica, e que agora novamente nos interessa por se tratar de uma das composições mais icônicas dessa angústia de quem não anseia cumprir o papel social regularizador das vidas pública e privada. Deparamo-nos ali com o pai que "horrorosamente se apresenta como pai profissional", o profissional qualificado, o que tem a vida privada devassada por vizinhos e companheiros de trabalho, aquele que consegue até não usar gravata "e tem outras pessoas e tem horas e tem ruas ó

11 Na poesia de Ruy Belo, notamos que é recorrente o uso da palavra gravata para representar esse mundo asfixiante e burocratizado. 
meu deus" (Belo 2009: 467). De modo que é precisamente por ter se aberto para as ruas que "o poeta fecha-se no quarto", como observa Drummond (1988: 18 e 19).

Não por acaso, se recordarmos outro poema do livro José, neste caso, «A Bruxa» - aquele em que o poeta diz: "Nesta cidade do Rio, / de dois milhões de habitantes, / estou sozinho no quarto, / estou sozinho na América. // Estarei mesmo sozinho?" (idem: 78) -, podemos decerto pensar no curto poema «Necrologia», de Homem de Palavra[s]:

Portugal tem nove milhões de habitantes

Lisboa talvez tenha um milhão

Nada disto me pode consolar bem sei

Morreu antónio gião

Eu não o conhecia nunca o conhecerei

(Belo 2009: 277)

Como podemos ver, Ruy Belo começa por igualmente indicar uma localização espacial e logo em seguida a caracteriza demograficamente, utilizando o número de habitantes para provocar uma sensação de amplitude, não obstante logo em seguida afunilada por aquele sentimento de "solidão assegurada pela multidão" (Belo 2009: 416), como diz noutro poema. É evidenciada, assim, a necrologia das grandes cidades, em que tudo se torna impessoal, e por isso mesmo a morte desse anônimo, que o poeta faz questão de lembrar que tem nome, ${ }^{12}$ pode muito bem funcionar como deslocamento metonímico da imagem obituária que ele reserva à metrópole - então tomada pela banalização da morte, que pode ser apenas mais uma breve notícia de jornal ou simplesmente um mote para conversa de café. De modo que haveria, portanto, uma espécie de sentença de morte para "estas nossas mecânicas cidades"; nelas, o sujeito poético gostaria de inaugurar "o dia o vasto espaço / das coisas sem gravata" (idem: 465). Ruy Belo partilha do mesmo sentimento daquele poeta que, em meio a milhões de habitantes, "Precisava de um amigo", como admite Drummond, em «A Bruxa». E tanto um quanto o outro inevitavelmente nos fazem pensar naquelas "Janelas do meu quarto, / Do meu quarto de um dos milhões do mundo que ninguém sabe quem é / (E se soubessem quem é, o que saberiam?)", já anunciadas por Álvaro de Campos (1993: 252), na sua «Tabacaria».

Desse modo, a cidade se torna, naquelas duas poesias, uma "protagonista coadjuvante", marcada por uma série de desencontros a que o poeta está fatalmente fadado na "selva de pedra", enquanto se reconhece, enfim, deambulador, naquele sentido flanêur ${ }^{13}$ instaurado por Baudelaire. "Deambulo nem triste nem alegre deambulo /

12 Curiosamente, uma das imagens atribuídas a António Gião (1906-1969), que parece ter vindo a se acentuar com o tempo, é a de um "eremita científico", um "físico isolado", que quase sempre desenvolveu os seus projetos sozinho e que "não conseguiu fazer discípulos", nas palavras de Carlos Fiolhais (2008). Professor catedrático da Universidade de Lisboa e diretor do Centro de Cálculo da Fundação Calouste Gulbenkian, ganhou notoriedade internacional por suas publicações sobre física de partículas e cosmologia. Apesar disso, acabou por ser "um cientista olvidado", como começa por dizer José Carlos Tiago Oliveira na tese de doutoramento A Personalidade Científica de António Gião, de 2012. É no mínimo curioso podermos associar essa dimensão de esquecimento à própria condição levantada pelo poema de Ruy Belo.

13 Observemos que "o flanêur não tem mais nada em comum com a figura tradicional 'do filósofo que passeia', mas 'adquire os traços do licantropo inquieto na selva social', como no 'Homem da multidão' de Edgar A. Poe" (Berardinelli 2007: 145). Na poesia de Ruy Belo, o poeta deambula por "caminho estreito perda dos meus passos / desse filósofo que estava a mais / quando já na verdade nada se produz” (Belo 2009: 579), como diz em $A$ 
deixo passos deambulantes em cidades cintilantes" (Belo 2009: 572), lemos em $A$ Margem da Alegria. Em vários momentos da poesia beliana encontramos passagens que nos levam a rememorar o poeta francês, com a sua mulher que passa: "sorrisos de mulheres que eu amei toda a manhã / vendo-as assim sentadas em esplanadas / para não mais as ver em minha vida" (idem: 805); "[...] o brilho nos olhos de uma mulher / que passa e passa decididamente decerto para sempre [...]" (idem: 629). Também em Drummond (1988: 122) essa temática é recorrente, desfazendo «O Mito» da idealização feminina ao dar lugar a essa mulher comum, anônima, distraída, que anda pelas ruas da cidade: "Sequer conheço Fulana, / [...] / Fulana jamais me vê, / Mas como eu amo Fulana", são os versos iniciais de um poema no qual o grifo maiúsculo de uma palavra tão prosaica quanto fulana, como se fosse nome próprio, já aponta para a ideia de que somos todos "indivíduos quaisquer" em meio à multidão. Por isso, a "musa" é feita da mesma matéria trivial do poeta: "Já não sofro, já não brilhas, / Mas somos a mesma coisa", conclui.

Sobre Baudelaire e o seu «A une passante», diz-nos Alfonso Berardinelli:

No soneto "A une passante", que o comentário de Benjamin tornou célebre, a cidade é protagonista absoluta e invisível, que só comparece acusticamente no primeiro verso ("La rue assourdissante autour de moi hourlait"). Mas, sem aquele lugar, aquele encontro - e o choque violento, extático e histérico que ele provoca -, isso seria impossível. A própria cidade é um lugar de estranhamento ("para o flâneur, sua cidade - ainda que ele tenha nascido nela, como Baudelaire - não é mais a sua pátria"): é o lugar da melancolia, da perda contínua, da passagem e da "irremediável caducidade" (Berardinelli 2007: 145).

Esse "mundo caduco", tantas vezes evocado pelo autor de «Mãos Dadas», é construído, portanto, por homens que se encontram enrodilhados na solidão e na incomunicabilidade (a solidão leva a que os homens desaprendam a linguagem com que se comunicam), e que se esbatem contra o cansaço, naquelas suas pequenas alienações diárias. ${ }^{14} \mathrm{O}$ medo os afunda nesse isolamento, de modo que tudo tende a retroalimentar aquela "irremediável caducidade", a partir da qual o poeta "indaga e experimenta a modernidade como inferno ou paraíso artificial, guiado por um sistema infalível de idiossincrasias hiper-seletivas" (Berardinelli 2007: 149). Tanto é que a noção de "fleurs du mal" é sugestivamente explorada por Ruy Belo através da insurreição do anonimato: "flor vagabunda ausente mesmo se presente / a meu lado na cadeira de um café" (Belo 2009: 693). Mais adiante, neste «Nem sequer não», o poeta ainda diz: "flor sempre para mim quase sem nome / ou tão mudável sempre que de instante para instante / eu tinha que lhe dar nome diferente" (idem: 694). Essa flor fica, então,

Margem da Alegria. E ainda em «Nau dos corvos»: “aqui estou eu sozinho todos os demais ficaram para trás / Aqui nada decorre e nada permanece / aqui os corvos são a solidão multiplicada" (idem: 450). Em Drummond, essas esferas são também auscultadas, como vemos no já citado «Canto ao homem do povo Charlie Chaplin», em que a alusão ao corvo de Poe se repete: “Assim, noturno cidadão de uma república / enlutada, surges a nossos olhos / pessimistas, que te inspecionam e meditam: / Eis o tenebroso, o viúvo, o inconsolado, / o corvo, o nunca-mais, o chegado muito tarde / a um mundo muito velho" (Andrade 1988: 180).

14 Recordemos o poema «Sim um dia decerto», no qual o sujeito poético, manifestando o seu cansaço e a dificuldade de se ver sozinho na multidão, leva-nos a entender que nunca aprendeu a "[...] estar à vontade na vida / a ser como alguém que desempenha um cargo e só faz as coisas que condizem com esse cargo / e não pensa que pode haver outras coisas que não sejam as coisas desse cargo" (Belo 2009: 675). 
"sob a pedra anónima" (idem: 695), inevitavelmente distante da romântica "Langage des Fleurs" e bem próxima daquele que vai propor "A linguagem da flor e das coisas sem voz!" (Baudelaire 2012: 89), encontrando beleza onde ela parece não existir - "E muita flor exala a medo / Seu perfume como um segredo / Na mais profunda solidão" (idem: 124). Em Drummond (1988: 97), também a flor “É feia. Mas é uma flor. Furou o asfalto, o tédio, o nojo e o ódio", como diz naquele seu conhecido poema «A flor e a náusea».

\section{A flor, no coração da máquina}

Em vista disso, podemos dizer que esse mundo "prosaico e moderno, um mundo que aparenta ser cada vez mais apoético, com suas metrópoles, sua multidão e suas máquinas" (Pagoto et. al 2008: 72), é que permite, decerto, que aquele espaço catacrésico de criação, que temos vindo a propor, tanto em Ruy Belo quanto em Drummond, seja resultado do que poderíamos chamar de "a máquina do mundo". ${ }^{15}$ Talvez as ambiguidades possíveis na leitura dessa máquina enquanto recompensa dos homens por suas conquistas terrenas, pelos seus feitos heróicos, como a que temos no canto camoniano (suportaríamos mesmo que todo o Conhecimento nos fosse revelado?), seja já naqueles dois poetas a sublinhada empatia pelos anti-heróis, aqueles destroçados pela guerra, os humilhados, os excluídos. ${ }^{16}$ Passemos a supor que a "máquina do mundo", naquelas duas obras, pode ser vista a partir daquela máquina que Chaplin propõe em Tempos Modernos. Ali, Carlitos, o eterno insubmisso, vai lutar para não ser apenas mais um elo nas engrenagens sociais, e quando absorvido pelo sistema (recordemos a antológica cena em que entra na máquina), acaba por encravar todo o mecanismo, minuciosamente organizado em seriações. "Charlot vai esforçar-se para fugir à lei da comunidade, vai esforçar-se para não se dissolver na massa anónima" (Leprohon s/d: 202).

A "máquina do mundo", esta que agora elaboramos, dentre tantas outras possíveis, fundamenta e estimula a repetição do nome, construindo um mundo repetitivo, num processo de saturação da palavra que se torna necessário àquele espaço catacrésico de criação. Assim, José, que em hebraico significa "aquele que acrescenta", é também o que se multiplica, garantindo a pluralidade uniformizada da multidão. Se bem repararmos, são vários josés-sem-nome que se proliferam e fomentam a obra de Chaplin, o que muitas vezes se manifesta pela substituição do nome próprio por um metônimo: o operário, o maquinista, o emigrante, o varredor, o artista, o caixeiro, o doceiro. De modo que "O canto não é o movimento das máquinas" (Andrade 1988: 96), e sim o canto dos excluídos, do artista que se vê à margem tanto quanto aqueles sobre os quais fala, tentando dar voz a esses "vagabundos que o mundo

15 A “máquina do mundo" tem sido um dos motes temáticos mais discutidos da poesia drummondiana. Para tanto, para entender outros pontos de análise que não serão aqui trabalhados ou mesmo as perspectivas que a fortuna crítica tem consolidado ao longo de décadas, sugerimos os trabalhos: Verso Universo em Drummond, de José Guilherme Merquior (1976); Carlos Drummond de Andrade: Análise da Obra, de Affonso Romano de Sant'Anna (1977); A Máquina do Mundo Repensada, de Haroldo de Campos (2000); Camões e a poesia brasileira -E o mito camoniano na língua portuguesa, de Gilberto Mendonça Teles (2001).

16 No Canto X, de Os Lusíadas, a deusa Tétis revela a "Máquina do Mundo" a Vasco da Gama, que a recebe dos deuses como recompensa por suas conquistas terrenas e seus feitos heróicos.. O Conhecimento acaba sendo revelado, então, através do funcionamento do Universo. 
repeliu" (idem: 179) (e o próprio Drummond, por sua vez, não acaba por dar voz à representação "muda" de Carlitos?). Podemos observar que Chaplin atende a uma multiplicidade de personagens que, na verdade, convergem na estranha unidade de uma personalidade "apenas sempre entretanto [ele] mesmo", como vai ainda dizer o autor de «Canto ao homem do povo Charlie Chaplin». O que nos lembra do legado de Baudelaire (1995: 41): "o poeta goza desse incomparável privilégio de poder, quando lhe agrada, ser ele mesmo e um outro".

Em meio a inúmeras máquinas, que ao mesmo tempo que tanto produzem parecem nada produzir, Ruy Belo e Carlos Drummond de Andrade - e, em certa medida, Carlitos, que apesar de tudo consegue se distanciar da máquina, mesmo tendo se tornado parte dela - demonstram crer que o poeta, se é o que podemos chamar de espírito livre, é-o não por ser capaz de se libertar da sociedade, mas porque consegue expressar a consciência da coletividade por sofrer daqueles mesmos males como qualquer outro homem, por ser profundamente individualista, tendo, entretanto, consciência disto, uma consciência que se alarga, inclusive, à medida que se espraia no trabalho poético. Reparemos, por exemplo, que a "máquina do mundo", em Ruy Belo, emaranha o sujeito poético: "Sopra sobre os meus dias forte o vento do norte / mata-me o mesmo sol que me dá vida / emaranha-me a máquina do mundo / e tudo era no fundo simples era nada mais do que passar" (Belo 2009: 711), como diz em «Discurso branco sobre fundo negro». O verbo utilizado é bastante sintomático, levando-nos a pensar em teia ou rede, noções fundamentais para o mundo conectado a que chegamos, com as suas solidões somatizadas. O poeta está tomado por tudo aquilo que esse mundo é, e que constitui inevitavelmente a sua subjetividade.

Em Drummond, «A Máquina do Mundo», em vez de permanecer fechada, contraída sobre si própria - como vimos, naquela poesia predominam "mil coisas aparentemente fechadas", que "quanto mais obscur[a]s mais falam", como lemos ainda em «Canto ao homem do povo Charlie Chaplin» - abre-se, "majestosa e circunspecta, / sem emitir um som que fosse impuro / nem um clarão maior que o tolerável" (Andrade 1988: 242). Acontece que, ainda assim, ela não vai conseguir chocar ou mesmo perturbar os sentidos e as intuições do poeta, que segue, "incurioso, lasso", o seu caminho. Diante de tantos absurdos familiarizados, não há como gastar ainda mais as já tão fatigadas retinas do poeta, que não vê propósito em se comunicar, em tempos de gente de "ouvidos moucos". A curiosidade exige entusiasmo, tudo o que um mundo marcado pela pobreza, violência e alienação não pode oferecer. A máquina, então, é recusada com todo o seu aliciante sistema, porque desde sempre enguiçada, pois tudo ali funciona para, condenado à partida, não funcionar. Por isso, o poeta segue, "vagaroso, de mãos pensas", o seu caminho.

Quanto a este final do poema, que lembra aquele já citado desfecho dos filmes de Chaplin, em que Carlitos segue se afastando ao longo de uma estrada, notemos que, frequentes na obra drummondiana, as mãos "aparecem como algo que se completa, se estende ao semelhante e deseja redimi-lo" e, neste caso, "a redenção do outro seria como a redenção dele próprio [poeta], justificado por essa adesão a algo exterior que ultrapassa a sua humanidade limitada" (Candido 2004: 79). Em Ruy Belo (2009: 437), persiste, do mesmo modo, a ideia das "mãos feitas para o pão e para a paz / mãos medida do homem não da máquina", e naquele próprio «Discurso branco sobre fundo negro», vemo-lo falar do "medo [que] tantos movimentos mobiliza", ao passo que se questiona: "E que fazer de objectos como as minhas duas mãos [...]?" (idem: 709). São ambos poetas que seguem "de mãos dadas" com a "vida presente", 
nas palavras de Drummond (1988: 68), na medida em que sabem que todos estão de "mãos dadas a esta geração destrutora vida ameaçada", como diria Ruy Belo (2009: 680). Em momento algum, quer num quer noutro poeta, é atenuado o desencanto diante do mundo ou a impotência de um destino que julgam falhado, pois a esperança não deixa de ser uma forma de consolo para o desespero. Permanece sempre o sentimento de um mundo equivocado, com a sua bizarra maquinaria, a pequenez dos ofícios ou a variedade das coisas (cf. Campos 2002: 147). "Estou na cidade grande e sou um homem / na engrenagem. Tenho pressa. Vou morrer", afirma Drummond (1988: 139), ao fazer um paralelo metafórico entre a «Morte no Avião» e aquela "morte particular e restrita do indivíduo" (cf. idem: 140), que nos assalta e nos faz "cair verticalmente", dia após dia.

Por isso mesmo podemos entender que, ainda que tomem atitudes contrárias diante da "máquina do mundo", quando esta lhes surge enquanto objeto, Ruy Belo e Drummond vão, do mesmo modo, demonstrar que a experiência do cotidiano se expande através de uma ação ética na unidade entre o poeta e o homem. Daí que seja difícil pensar numa separação entre visão social e lirismo, naquelas duas obras, que entendem que a função social da poesia é se preocupar em dar a ver o mundo que aí está, e não "salvá-lo". Reparemos, aliás, que

Para quem o lia em Portugal, Drummond tinha conseguido realizar algo que, do lado de cá do Atlântico, era encarado com cepticismo e preconceito: a possibilidade de produzir uma poesia social e política que, não recuando ante a verberação e a denúncia indignada das hipocrisias, das injustiças, das monstruosidades, que nessa esfera se situam, o fizessem sem perda de qualidade artística. [...] O nosso neo-realismo, afinal bem mais sucedido na poesia lírica que na social, nunca nos havia dado nada equivalente - e tivemos de esperar pela década de 60 para ver poetas como Sophia de Mello Breyner Andresen. Ruy Belo ou Luiza Neto Jorge, entre outros, enveredarem por uma escrita altamente qualificada de poesia política (Cruz 2008: 378 e 379).

As modulações de uma poesia participativa, em tais obras, se têm algo de comum, é que se revelam sob pequenas histórias ou certos dramas corriqueiros que, através da existência de cada um de nós, vão dando conta dos aspectos e das inquietações da sociedade moderna. Partindo da ideia de que "Camões viveu no momento da epopeia e a única epopeia hoje possível é a que Fernando Pessoa nos deu na Mensagem", como afirma Ruy Belo (2002: 32), podemos dizer que estamos diante de outros dois poetas que conseguem nos oferecer a única epopeia possível aos nossos dias, a epopeia da vida moderna, que só poderia ser conseguida, afinal, por autores com tamanha envergadura. Para Eduardo Lourenço (2002: 217), a respeito da poesia de Ruy Belo, “a sua 'epopeia' não está ao serviço de nada, é intrinsecamente poética, confronto com os escolhos absolutos do Destino", naquela "aventura assumidamente desesperada e épica que é a sua quotidiana vida". Já nas palavras de Gastão Cruz (2008: 382), desta vez sobre Drummond, "teremos, creio, de remontar a Camões, se quisermos encontrar um poeta que nos fale tão directamente e sem disfarce dos seus (?) sentimentos, sem que a poesia perca (pelo contrário, só ganhe) com isso". São poesias que, no seu individualismo, são ainda mais humanas, porque precarizadas pela própria condição do mundo em que o sujeito poético vive. 
Assim, tanto em Ruy Belo quanto em Drummond, essas preocupações de cunho participante (no sentido bandeiriano, queremos dizer) enriquecem a fundamentação lírica de suas obras, podendo ser mesmo concebidas como "poesias maiores" numa perspectiva que contraria aquela visão que desagrega poesia social e poesia lírica. Por meio de uma acentuada consciência artística, que é também uma consciência social e política, portanto, aqueles autores atingem

a plenitude, a cristalização, a humanização, sob uma forma suave e terna, em que cada um mergulha no lençol profundo de sua província e de seus antepassados para melhor compreender "a máquina do mundo", a angústia de seu tempo, o desarvoramento do homem contemporâneo, com um largo sentimento de fraternidade (Coutinho 1967: 11).

Se a beleza de um filme como Tempos Modernos, segundo Pierre Lephoron (s/d: 204), resulta "da ternura capaz de ligar duas pessoas numa sociedade inumana, no meio de um mundo hostil", diríamos que é também essa mesma ternura um dos mais marcantes traços de resistência na poesia de Ruy Belo e na de Carlos Drummond de Andrade. Defendendo acima de tudo a dignidade humana, e se compadecendo diante da alienação desses "homens-máquinas de coração mecânico", como se diz naquele filme, deparamo-nos com obras nas quais a flor, para a ela regressarmos, ainda persiste - apesar de feia e com o seu nome provisório. A flor. Apanhada do cesto de uma jovem cega vendedora de flores, como vemos em Chaplin, ou aquela que brota do asfalto, em Drummond, ou ainda, em Ruy Belo, a que cresce no centro da cidade tumultuosa. Despertos para a dor do mundo, individual e coletiva, aqueles autores sabem o quão os tempos de crise refratam a crise dos tempos.

\section{Referências bibliográficas}

Andrade, Carlos Drummond de (1988): Poesia e Prosa. Vol. único. Rio de Janeiro: Nova Aguilar.

Andrade, Carlos Drummond de (2002): Maria Julieta entrevista Carlos [entrevista a Maria Julieta Drummond de Andrade, CD]. Rio de Janeiro: Luz da Cidade.

Athayde, Tristão de (1969): Meio Século de Presença Literária. José Olympio: Rio de Janeiro.

Baudelaire, Chales (1995): O Spleen de Paris. Pequenos poemas em prosa. Rio de Janeiro: Imago.

Barthes, Roland (1987): O Prazer do Texto. Trad. de J. Guinsburg. São Paulo: Editora Perspectiva.

Belo, Ruy (2009): Todos os Poemas. $3^{\text {a }}$ ed. Lisboa: Assírio \& Alvim.

Belo, Ruy (2002 [1969]): Na Senda da Poesia. Ed. de Maria Jorge Vilar de Figueiredo. Lisboa: Assírio \& Alvim.

Berardinelli, Alfonso (2007): Da Poesia à Prosa. Ed. de Maria Betânia amoroso. Trad. de Maurício Santana Dias. São Paulo: Cosac Naify.

Bosco, Francisco (2004): "Roland Barthes, entre o clássico e a vanguarda". ALEA n.1 vol.6: 43-52.

Campos, Álvaro de (1993): Poesias de Álvaro de Campos. Lisboa: Ática.

Campos, Haroldo de (2013): Metalinguagem \& Outras Metas. $4^{a}$ ed. São Paulo: Perspectiva. 
Campos, Maria do Carmo (2002): "Imagens Urbanas na Poesia de Drummond", in Leituras de Drummond. Flávio Loureiro Chaves (ed.), Caxias do Sul, EDUCS, pp. 133-151.

Candido, Antonio (2004): Vários Escritos. São Paulo / Rio de Janeiro: Duas Cidades / Ouro sobre Azul.

Coutinho, Afrânio (1967): "Nota editorial", in Obra Completa, de Carlos Drummond de Andrade, vol. único. Rio de Janeiro: José Aguilar.

Cruz, Gastão (2008): A Vida da Poesia. Lisboa: Assírio \& Alvim.

Faustino, Mário (2003): De Anchieta aos Concretos. Ed. de Maria Eugenia Boaventura. São Paulo: Companhia das Letras.

Fiolhais, Carlos (2008): "Um eremita científico", Gazeta de Física n. 3 vol. 31: 22.

Gusmão, Manuel (2010): Tatuagem \& Palimpsesto - Da poesia em alguns poetas e poemas. Lisboa: Assírio \& Alvim.

Holanda, Sério Buarque de (1996): O Espírito e a Letra: Estudos de crítica literária (19471958). Vol. 2. Ed. de Antonio Arnoni Prado. São Paulo: Companhia das Letras.

Leprohon, Pierre (s/d): Charles Chaplin. Trad. de Alberto Seixas Santos. Lisboa: Edição «Livros do Brasil» Lisboa.

Lima, Jorge de (1958): Obra Completa. Vol.1. Rio de Janeiro: José Aguilar.

Lourenço, Eduardo (2002): "[Em louvor do vento]”, in Século de Ouro, Antologia Crítica da Poesia Portuguesa do Século XX, de Osvaldo Silvestre e Pedro Serra (eds.). Braga / Coimbra / Lisboa: Cotovia / Angelus Novus, pp. 215-218.

Martelo, Rosa Maria (2012): O Cinema da Poesia. Lisboa: Documenta.

Pagoto, Cristian; Souza, Adalberto de Oliveira (2008): “A cidade como Palco da Modernidade: De Paris, de Baudelaire, ao Rio de Janeiro, de Drummond", Revista Cerrados n.26 vol.17: 59-74.

Pia, Pascal (1959): Baudelaire-Par lui-même. Bourges: Aux Éditions du Seuil.

Rosa, António Ramos (1986): Poesia, Liberdade Livre. Lisboa: Ulmeiro.

Rosa, António Ramos (1997): 21 Poemas Escolhidos. Sel. de Maria Filipe Ramos Rosa. Lisboa: Civilização / Contexto.

Rowland, Clara (2015): “Conspiração de folhas: Ruy Belo e o livro de poesia", in Literatura Explicativa: Ensaios sobre Ruy Belo, de Manaíra Aires Athayde (ed.). Lisboa: Assírio \& Alvim, pp. 257-272.

Sant'Anna, Affonso Romano (1972): Drummond: O gauche no tempo. Rio de Janeiro: Lia / INI.

Santiago, Silviano (1966): “Camões e Drummond: a máquina do mundo", Hispania n.3 v. 49: 389-394.

Saraiva, Arnaldo (1989): Carlos Drummond de Andrade: 65 anos de Poesia. Lisboa: O Jornal.

Serra, Pedro (2003): Um Nome para Isto - Leituras da poesia de Ruy Belo. Coimbra: Angelus Novus.

Silvestre, Osvaldo Manuel (1997): "Introdução", in O Problema da Habitação - Alguns Aspectos, de Ruy Belo. Lisboa: Editorial Presença, pp. 7-20.

Simões, João Gaspar (1999): Crítica II. Poetas Contemporâneos 1938-1961. Tomo I. Lisboa: Imprensa Nacional / Casa da Moeda, 1999.

Smolik, Pierre (2015): The Freak - Chaplin's Last Film. Genebra: Call Me Edouard.

Sterzi, Eduardo (2002): "Drummond e a poética da interrupção", in Drummond Revisitado, de Reinaldo Damazio (ed.). São Paulo: Unimarco Editora, pp. 49-90.

Studart, Júlia (2013) "Uma condição horizontal", in O Problema da Habitação - Alguns Aspectos, de Ruy Belo. Rio de Janeiro: 7Letras, pp. 7-10. 
Teles, Gilberto Mendonça (1970): Drummond - A Estilística da Repetição. Rio de Janeiro: José Olympio. 